\title{
lleostomy for steroid-resistant acute graft-versus-host disease of the gastrointestinal tract
}

\author{
Amin T. Turki ${ }^{1}$ (D) Evren Bayraktar ${ }^{1}$. Oliver Basu ${ }^{2} \cdot$ Tamas Benkö $^{3} \cdot \mathrm{Ji}^{-H e e} \mathrm{Yi}^{1} \cdot$ Jan Kehrmann $^{4} \cdot$ Asterios Tzalavras $^{1}$. \\ Tobias Liebregts $^{1} \cdot$ Dietrich W. Beelen $^{1} \cdot$ Nina K. Steckel ${ }^{1}$
}

Received: 8 February 2019 / Accepted: 2 July 2019 / Published online: 23 July 2019

(C) Springer-Verlag GmbH Germany, part of Springer Nature 2019

\begin{abstract}
Steroid-resistant acute graft-versus-host disease (GVHD) of the gastrointestinal tract associates with important morbidity and mortality. While high-dose steroids are the established first-line therapy in GVHD, no second-line therapy is generally accepted. In this analysis of 65 consecutive patients with severe, steroid-resistant, intestinal GVHD (92\% stage 4), additional ileostomy surgery significantly reduced overall mortality (hazard ratio $0.54 ; 95 \%$ confidence interval, $0.36-0.81 ; p=0.003$ ) compared to conventional GVHD therapy. Median overall survival was 16 months in the ileostomy cohort compared to 4 months in the conventional therapy cohort. In the ileostomy cohort, both infectious- and GVHD-associated mortality were reduced (40\% versus $77 \%)$. Significantly declined fecal volumes $(p=0.001)$ after surgery provide evidence of intestinal adaptation following ileostomy. Correlative studies indicated ileostomy-induced immune-modulation with a $>50 \%$ decrease of activated $\mathrm{T}$ cells $(p=0.04)$ and an increase in regulatory T cells. The observed alterations of the patients' gut microbiota may also contribute to ileostomy's therapeutic effect. These data show that ileostomy induced significant clinical responses in patients with steroidresistant GVHD along with a reduction of pro-inflammatory immune cells and changes of the intestinal microbiota. Ileostomy is a treatment option for steroid-resistant acute GVHD of the gastrointestinal tract that needs further validation in a prospective clinical trial.
\end{abstract}

Keywords Hematopoietic stem cell transplantation · Graft-versus-host disease · Refractory GVHD · Intestinal adaptation · Ileostomy-induced immune modulation $\cdot$ Intestinal microbiota

Electronic supplementary material The online version of this article (https://doi.org/10.1007/s00277-019-03754-3) contains supplementary material, which is available to authorized users.

Amin T. Turki

amin.turki@uk-essen.de

Evren Bayraktar

evren.bayraktar@uk-essen.de

Oliver Basu

oliver.basu@uk-essen.de

Tamas Benkö

tamas.benkoe@uk-essen.de

Ji-Hee Yi

ji-hee.yi@uk-essen.de

Jan Kehrmann

jan.kehrmann@uk-essen.de

Asterios Tzalavras

Asterios.tzalavras@uk-essen.de
Tobias Liebregts

tobias.liebregts@uk-essen.de

Dietrich W. Beelen

Dietrich.beelen@uk-essen.de

Nina K. Steckel

nina-kristin.steckel@uk-essen.de

1 Department of Bone Marrow Transplantation, West-German Cancer Center, University Hospital Essen, Hufelandstrasse, 55

45122 Essen, Germany

2 Department of Pediatric Stem Cell Transplantation, Center of Pediatrics III, University Hospital Essen, Essen, Germany

3 Department of General-, Visceral- and Transplantation Surgery, University Hospital Essen, Essen, Germany

4 Institute of Medical Microbiology, University Hospital Essen, Essen, Germany 


\section{Introduction}

Despite numerous advances in allogeneic stem cell transplantation (aSCT) during the last decades, acute graft-versus-host disease (aGVHD) remains a major source of morbidity and mortality [1]. In particular, aGVHD of the gastro-intestinal tract (GI-aGVHD) is a major threat to allogeneic stem cell recipients and challenges physicians [2]. In steroid-resistant disease [3], treatment effects are insufficient, hospitalizations extend over months, and patient recovery is complicated by nosocomial infections. In the past, a long list of immunemodulating drugs has been investigated in order to enhance treatment results, with limited effect and no significant difference between treatments [4-8]. In retrospective analyses, antithymocyte globulin (ATG) [9] and ruxolitinib [10] were identified as most promising treatments; nevertheless, only a limited fraction of patients in these studies had GI-aGVHD. As a consequence, consensus guidelines recommend the use of high-dose steroids as a first-line treatment, while no standard second-line treatment is generally accepted $[4,11]$.

Ileostomy is an established surgical procedure, regularly performed in patients with colon cancer resection and in few cases of patients with inflammatory bowel disease. Pre-clinical studies indicated physiological alterations following ileostomy, such as increased intestinal absorption and mucosal proliferation, which might be of therapeutic use in GVHD. Intestinal adaptation [12] after ileostomy has been shown in animal models of surgeryinduced short bowel syndrome [13] in piglets [14], zebrafish [15], and mice [16], resulting in mucosal hyperplasia through significantly greater crypt depth and villi length. In an ileostomy mouse model, adaptation processes resulted in decreased expression of secretory progenitor cells' stem cell markers such as protein atonal homolog 1 [16]. In an intestinal resection model, the ileum had a higher adaptive capacity than jejunum, duodenum, or colon [17] and signaling pathways involving molecules, such as insulin-like growth factor [17] or epidermal growth factor receptor (EGFR), have been induced. In zebrafish, EGFR expression significantly increased after ileostomy [15]. EGFR can prevent apoptosis [18], is co-expressed on regulatory T cells [19], and may contribute to immune homeostasis. Little is known on the pathophysiology of ileostomy-induced immune modulation. Patients with inflammatory bowel disease after total proctocolectomy and primary ileostomy rarely develop de novo Crohn's disease in their neo-small bowel [20]. However, surgery may also induce inflammatory bowel disease [21] or celiac disease in predisposed patients. Amphiregulin, an EGFR agonist involved in autocrine growth stimulation, is weakly expressed in intestinal biopsies of GVHD patients [22] and present at elevated levels in the serum of patients with aGVHD- [22] and lateaGVHD [23]. The status of surgical interventions in GI-aGVHD is controversial due to observed complication and mortality rates [24]. Previous case reports indicated the feasibility of great bowel surgery in patients with GVHD, but left ileostomy's status in GI-
aGVHD ill-defined. Cases included 2 young adults with great bowel resection for complications of aGVHD [25], 2 cases of small bowel resection in chronic GVHD [26], and one elderly patient with laparoscopic left hemicolectomy in late-aGVHD [27]. None of the above-cited reports actually intended to treat aGVHD with ileostomy, neither compared ileostomy to other therapeutic options. To our knowledge, this study is the first description of ileostomy for the treatment of steroid-resistant, GI-aGVHD. At the same time, our data report the largest aGVHD patient cohort with performed ileostomy surgery along with a matched stage 4 GI-aGVHD cohort.

\section{Methods}

\section{Patients}

We retrospectively analyzed clinical characteristics and laboratory parameters of patients with severe intestinal GVHD after allogeneic stem cell transplantation. All patients who underwent allogeneic hematopoietic stem cell transplantation (HSCT) in the Bone Marrow Transplantation units of the West-German Cancer Center at University Hospital Essen between September 2009 and December 2015 were included in this study. From all 1353 consecutive transplanted patients that were screened, 65 developed severe, intestinal GVHD. Patients were followed for up to 5 years after transplantation. Overall survival (OS) was calculated from transplantation to last follow-up visit or death of any cause.

\section{Treatment}

All patients received conventional GVHD prophylaxis regimen (Table 1). Medical therapy for steroid-resistant aGVHD was according to physician's choice (Table 2). In the experimental cohort, 10 patients consented to undergo experimental, individual therapy and received additional ileostomy surgery as salvage treatment for severe-, refractory-, steroid-resistant aGVHD. Surgery was performed at the Department of General-, Visceral- and Transplantation Surgery at the University Hospital Essen. The surgical procedure was according to physician's choice. The following procedures were performed: loop ileostomy (7 patients), loop jejunostomy (2 patients), and 1 patient received a loop ascendostoma. Patients of the conventional therapy cohort received second- and further-line treatments according to physician's choice.

\section{Assessments}

GVHD was classified according to published criteria for aGVHD $[28,29]$. In the experimental cohort, GI-aGVHD was further histologically confirmed according to the Freiburg criteria [30]. For inpatients, daily clinical assessment 
Table 1 Patient baseline characteristics

\begin{tabular}{|c|c|c|c|c|}
\hline \multirow[t]{2}{*}{ Characteristic } & \multicolumn{2}{|c|}{ Conventional therapy plus ileostomy } & \multicolumn{2}{|c|}{ Conventional therapy } \\
\hline & $n$ & $\%$ & $n$ & $\%$ \\
\hline Total enrolled and treated & 10 & 100 & 55 & 100 \\
\hline \multicolumn{5}{|l|}{ Demographics } \\
\hline Median age at transplantation (range) & 49 & $(2-53)$ & 57 & $(6-73)$ \\
\hline Female sex & 3 & 30 & 25 & 45 \\
\hline \multicolumn{5}{|l|}{ Disease } \\
\hline Acute myeloid leukemia & 3 & 30 & 22 & 40 \\
\hline Myelodysplastic syndromes & 0 & 0 & 11 & 20 \\
\hline Acute lymphoblastic leukemia & 1 & 10 & 6 & 11 \\
\hline Bilinear acute leukemia & 0 & 0 & 1 & 2 \\
\hline Chronic lymphocytic leukemia & 1 & 10 & 1 & 2 \\
\hline Chronic myeloid leukemia & 0 & 0 & 3 & 5 \\
\hline Chronic myelomonocytic leukemia & 0 & 0 & 2 & 4 \\
\hline Myeloproliferative disorders & 1 & 10 & 4 & 7 \\
\hline Aggressive lymphomas & 1 & 10 & 3 & 5 \\
\hline Hodgkin lymphomas & 0 & 0 & 1 & 2 \\
\hline Dendritic cell neoplasia & 1 & 10 & 0 & 0 \\
\hline Severe aplastic anemia & 1 & 10 & 0 & 0 \\
\hline Congenital disorders & 1 & 10 & 1 & 2 \\
\hline \multicolumn{5}{|l|}{ Viral serostatus prior transplantation } \\
\hline CMV positive donor/recipient & 10 & 100 & 19 & 35 \\
\hline EBV positive donor/recipient & 5 & 50 & 55 & 100 \\
\hline \multicolumn{5}{|l|}{ Conditioning and irradiation } \\
\hline Myeloablative conditioning regimen & 10 & 100 & 37 & 67 \\
\hline Anti-thymocyte globulin containing & 5 & 50 & 25 & 45 \\
\hline Total body irradiation containing & 3 & 30 & 15 & 27 \\
\hline \multicolumn{5}{|l|}{ Transplant and donor constellation } \\
\hline Unrelated donor & 7 & 70 & 42 & 76 \\
\hline Sibling donor & 3 & 30 & 12 & 22 \\
\hline Median $\mathrm{CD} 34^{+}$cells $/ \mathrm{kg}\left[\times 10^{6}\right]$, range & 5.4 & $3.7-17.3$ & 7.4 & $3.4-9.4$ \\
\hline \multicolumn{5}{|l|}{ Mismatch constellation } \\
\hline HLA A mismatch & 2 & 20 & 8 & 15 \\
\hline HLA B mismatch & 0 & 0 & 6 & 11 \\
\hline HLA C mismatch & 1 & 10 & 2 & 4 \\
\hline HLA DQ mismatch & 1 & 10 & 3 & 5 \\
\hline HLA DR mismatch & 0 & 0 & 1 & 2 \\
\hline Male recipient female donor & 2 & 20 & 7 & 13 \\
\hline Female recipient male donor & 2 & 20 & 11 & 20 \\
\hline \multicolumn{5}{|l|}{ Baseline immunosuppression } \\
\hline Cyclosporin A & 10 & 100 & 49 & 89 \\
\hline Methotrexate & 9 & 90 & 46 & 84 \\
\hline Tacrolimus & 1 & 10 & 3 & 5 \\
\hline Mycophenolate mofetil & 3 & 30 & 14 & 25 \\
\hline
\end{tabular}

$H L A$ human leukocyte antigen, $C M V$ cytomegalovirus, $E B V$ Epstein-Barr virus and standard laboratory parameters were obtained. Fecal volumes were assessed 7 and 14 days before and after ileostomy and confirmed before discharge. For outpatients, clinical status and laboratory parameters were recorded weekly. Response to therapy and outcome were assessed according to published criteria [31]. A partial response (PR) in 
Table 2 GVHD patient characteristics

\begin{tabular}{|c|c|c|c|c|}
\hline \multirow[t]{2}{*}{ Characteristic } & \multicolumn{2}{|c|}{ Conventional therapy plus ileostomy } & \multicolumn{2}{|c|}{ Conventional therapy } \\
\hline & $n$ & $\%$ & $n$ & $\%$ \\
\hline Total enrolled and treated & 10 & 100 & 55 & 100 \\
\hline \multicolumn{5}{|l|}{ Overall GVHD grade } \\
\hline III & 0 & 0 & 6 & 11 \\
\hline IV & 10 & 100 & 49 & 89 \\
\hline \multicolumn{5}{|c|}{ Gastrointestinal GVHD stage } \\
\hline 3 & 0 & 0 & 8 & 15 \\
\hline 4 & 10 & 100 & 47 & 85 \\
\hline \multicolumn{5}{|l|}{ Liver GVHD stage } \\
\hline 1 & 3 & 30 & 4 & 7 \\
\hline 2 & 1 & 10 & 5 & 9 \\
\hline 3 & 4 & 40 & 9 & 16 \\
\hline 4 & 2 & 20 & 10 & 18 \\
\hline \multicolumn{5}{|l|}{ Skin GVHD stage } \\
\hline 1 & 1 & 10 & 0 & 0 \\
\hline 2 & 4 & 40 & 13 & 24 \\
\hline 3 & 1 & 10 & 20 & 36 \\
\hline 4 & 2 & 20 & 10 & 18 \\
\hline GVHD biomarkers & Median & Range & Median & Range \\
\hline Serum s-IL2 R & 696 & $409-6960$ & 673 & $182-23997$ \\
\hline Fecal calprotectin & 3000 & $124-3079$ & 360 & $47-3010$ \\
\hline
\end{tabular}

GVHD graft-versus-host disease, $s$-IL2 $R$ soluble interleukin-2 receptor
aGVHD evaluation required organ staging improvement, without deterioration of any other organ, and a complete response (CR) required resolution of aGVHD manifestation in all organs. No response corresponded to any change and progression to a flare of GVHD after initial response. For responding patients, follow-up intervals were sequentially extended. Patient outcome was evaluated from date of transplantation until death of any cause or last follow-up. Adverse events were graded according to Common Terminology Criteria for Adverse Events (CTCAE) 4.0 [32]. At diagnosis of steroid-resistant GVHD, Eastern Cooperative Oncology Group (ECOG) general performance score and Charlson Comorbidity Index scores were obtained for all patients. Conditioning- and early transplant-related complications were included into comorbidity calculation.

\section{Correlative studies}

We collected blood serum and - in a subset of patients - stool samples from the experimental and conventional therapy cohort before and after ileostomy. Serum-soluble interleukin-2 receptor (s-IL2 R) levels were assessed according to laboratory standards [33]; fecal calprotectin analysis was performed as previously published [34]. All analyses were performed at the University Hospital Essen and its laboratories. Quantification of the gut microbiota from stool samples was performed in the
Institute of Medical Microbiology. A four-quadrant sequential streak technique on agar plates was used for semi-quantitative analysis of bacteria and fungi. Stool samples were plated on C.L.E.D. agar (cystine lactose electrolyte-deficient agar) for aerobic bacteria and Beerens agar with sheep blood for anaerobic bacteria and fungi selective agar (all from Thermo Scientific, Waltham, MA). Quantification of grown colonies was routinely assessed after $24 \mathrm{~h}$ of culture for aerobic bacteria and fungi and after $48 \mathrm{~h}$ for anaerobic bacteria. Presence of bacteria and fungi was categorized as low, medium, or high according to culture counts. Bacteria and fungi were quantified as low for growth of 0 to $<5$ colonies in sector 1 , medium for growth of $\geq 5$ colonies in sector 1 to $<5$ colonies in sector 3 , and high for growth of $\geq 5$ colonies in sector 3 or in sector 4 .

Peripheral blood mononuclear cells (PBMC) were isolated using an automatic red blood cell lysing system (TQ-Prep, Beckman Coulter, Brea, CA), washed with fluorescenceactivated cell sorting (FACS) buffer and stained with surface markers. No intracellular staining was performed. FACS analysis of the patient's immune status was performed on a FC500 and NAVIOS flow cytometer (Beckman Coulter) using the manufacturer's software. A minimum of 15,000 lymphocytes were analyzed to ensure adequate subset analysis. Specific cell subsets within the $\mathrm{CD} 45^{+}$lymphocyte gate were characterized as following: $\mathrm{T}$ cells, $\mathrm{CD}^{+}$; $\mathrm{T}$ helper cells, $\mathrm{CD}^{+} / \mathrm{CD}^{+}$; activated $\mathrm{T}$ cells, $\mathrm{CD}^{+} / \mathrm{HLA}^{-\mathrm{DR}^{+}}$; regulatory $\mathrm{T}$ cells, $\mathrm{CD}^{+} /$ 
$\mathrm{CD} 4^{+} / \mathrm{CD} 25^{+} / \mathrm{CD} 127^{-}$; cytotoxic $\mathrm{T}$ cells, $\mathrm{CD}^{+} / \mathrm{CD} 8^{+}$; naïve $\mathrm{CD}^{+}{ }^{+} \mathrm{T}$ cells, $\mathrm{CD}^{+} / \mathrm{CD}^{+} / \mathrm{CD} 45 \mathrm{RA}^{+} ;$memory $\mathrm{CD} 4^{+} \mathrm{T}$ cells, $\mathrm{CD}^{+} / \mathrm{CD}^{+} / \mathrm{CD} 45 \mathrm{RO}^{+} ; \mathrm{B}$ cells, $\mathrm{CD} 19^{+}$.

\section{Statistical analysis}

For statistical analysis, we used Statistical Package for the Social Sciences (SPSS) software (SPSS 23.0; SPSS Inc., Chicago, IL) and Matlab (Mathworks Inc., Nantick, MA). Clinical-pathological parameters were compared using chisquare tests. Overall survival (OS) was calculated from date of allogeneic stem cell transplantation until death from any cause. OS of surviving patients was censored at 60 months. Survival curves were obtained by using the Kaplan-Maier method and were compared by the log-rank test. All $p$ values are two-sided at the significance level of 0.05 . Cox proportional hazards model was adopted to calculate the hazard rate. Multivariate and univariate Cox regression analysis was performed for competing risks and subgroup analysis using SPSS software. The statistical significance of changes, as a result of an intervention, was evaluated by testing before- and aftervalues with a paired t test in Matlab.

\section{Results}

\section{Patient characteristics}

All 1353 consecutive patients receiving allogeneic stem cell transplantation at the University Hospital Essen between September 2009 and December 2015 were screened. A total of 65 patients were diagnosed with severe, GI-aGVHD. Underlying hematologic disease, donor constellation, viral serostatus, conditioning regimen, and baseline immunosuppression are detailed in Table 1. Of the total 65 patients with severe aGVHD, 10 underwent experimental surgical treatment for steroid-resistant GVHD in addition to conventional therapy, while the remaining 55 patients received only conventional medical therapy (Table 1). Patients of the experimental cohort were 8 adult and 2 pediatric patients. Differences between both cohorts involved diagnosis of myelodysplastic syndrome (0\% versus (vs) $20 \%$ ), myeloablative conditioning regimen $(100 \%$ vs $67 \%)$, cytomegalovirus (CMV) risk profile serostatus (100\% vs $35 \%)$, and Epstein-Barr virus (EBV) risk serostatus (50\% vs $100 \%$ ). Established GVHD risk factors were evenly distributed between cohorts, with unrelated donor stem cells $(70 \%$ vs $76 \%$ ) and HLA mismatch (40\% vs $37 \%$ ). Half of the patients in both cohorts received GVHD prophylaxis with ATG as part of their conditioning regimen. All patients of the ileostomy cohort and $85 \%$ of the conventional therapy cohort developed stage 4 GI-aGVHD (Table 2). Patients had GVHD of more than one site including stage $3-4$ liver $(60 \%$ vs $34 \%)$ and stage
3-4 skin GVHD (30\% versus 54\%). Comparison of ECOG performance and Charlson comorbidity scores at diagnosis of steroid-resistant GVHD between ileostomy and conventional therapy cohort revealed no significant difference (Supplementary Table 1).

\section{Therapy and response}

All 65 patients received a first-line GVHD treatment with high-dose steroids. Dosage of steroids was according to physician's choice between 2 and $3 \mathrm{mg} / \mathrm{kg}$ bodyweight, with a weekly tapering following response. Patients' first-, second-, and further-line GVHD treatments reflecting consensus recommendations and experimental approaches in refractory disease are detailed in Table 3. The majority of patients achieved a partial response (PR) through second-line therapy, except for their GI-aGVHD, which poorly responded or flared. In the experimental ileostomy cohort, all patients $(n=10)$ were pretreated with several second-line treatments, before being considered for salvage ileostomy. Ileostomy was performed at a median of 134 days (range 32 to 366) after allogeneic transplantation. Early surgery-associated morbidity was low (grade $\leq 2 \mathrm{CDCAE}$ ) and no intervention-associated mortality was recorded. All patients required limited red blood transfusions for moderate bleeding during and shortly after surgery. No early surgical intervention for bleeding was necessary. One non-responding patient required surgical intervention for wound dehiscence 2 months after ileostomy (grade 3 CDCAE). After ileostomy, median fecal volumes significantly declined by $50 \%$ (Fig. 1), despite a shortened resorption surface. At discharge, fecal volumes were significantly lower than in the early post-operative phase $(p<0.005)$. GVHDassociated gastrointestinal bleeding was reduced and patients reported a significantly improved individual pain assessment. Eight patients $(80 \%)$ had a complete response (CR) of their aGVHD and could be discharged at a median time of 62 days after ileostomy (range 14-199). In 3 patients (30\%), ileostomy was temporary and successfully removed after 5 months.

Accordingly with published results for patients with grade IV GVHD, 90\% of patients deceased during the follow-up period of over 5 years (Fig. 2), but with important differences between both therapy cohorts. In the ileostomy cohort, the 5year OS was significantly ( $p=0.002)$ higher than in the conventional therapy cohort ( $30 \%$ vs $6 \%$ ). The leading cause of death in the conventional therapy cohort was infectious disease $(56 \%)$ including sepsis, aspergillosis, and respiratory failure, followed by uncontrolled GVHD (31\%) (Table 3). Both aGVHD-related mortality (10\% vs $31 \%$ ) and mortality caused by severe infection ( $20 \%$ vs $56 \%$ ) were significantly lower in the ileostomy cohort. All respective causes of death are detailed in Table 2. The majority of patients in both cohorts developed aGVHD in more than one site. Response of cutaneous aGVHD was regularly achieved through first- or 
Table 3 Therapy and response

\begin{tabular}{|c|c|c|c|c|}
\hline \multirow[t]{2}{*}{ Characteristic } & \multicolumn{2}{|c|}{ Conventional therapy plus ileostomy } & \multicolumn{2}{|c|}{ Conventional therapy } \\
\hline & $n$ & $\%$ & $n$ & $\%$ \\
\hline Total enrolled and treated & 10 & 100 & 55 & 100 \\
\hline \multicolumn{5}{|l|}{ GVHD therapy } \\
\hline Cyclosporin A & 10 & 100 & 49 & 89 \\
\hline Tacrolimus & 3 & 30 & 7 & 13 \\
\hline Prednisolone & 10 & 100 & 54 & 98 \\
\hline Methylprednisolone & 0 & 0 & 1 & 2 \\
\hline Anti-thymocyte globulin & 5 & 50 & 23 & 42 \\
\hline Mycophenolate mofetil & 3 & 30 & 10 & 18 \\
\hline Ruxolitinib & 3 & 30 & 3 & 5 \\
\hline Basiliximab & 1 & 10 & 9 & 16 \\
\hline Infliximab & 4 & 40 & 0 & 0 \\
\hline Sirolimus & 3 & 30 & 0 & 0 \\
\hline Alemtuzumab & 0 & 0 & 2 & 4 \\
\hline Azathioprine & 1 & 10 & 0 & 0 \\
\hline Cyclophosphamide & 0 & 0 & 1 & 2 \\
\hline Mesenchymal stem cells & 2 & 20 & 1 & 2 \\
\hline \multicolumn{5}{|l|}{ GVHD response after second-line treatments } \\
\hline Complete response & 0 & 0 & 4 & 7 \\
\hline Partial response & 7 & 70 & 29 & 53 \\
\hline No response & 3 & 30 & 22 & 40 \\
\hline Progression & 3 & 30 & 13 & 24 \\
\hline \multicolumn{5}{|l|}{ Ileostomy cohort characteristics } \\
\hline Time to event in days & Median & Range & & \\
\hline GVHD diagnosis to ileostomy & 58 & $20-215$ & - & - \\
\hline Allogeneic transplantation to ileostomy & 134 & $32-366$ & - & - \\
\hline Surgery to discharge & 62 & 14-199 & - & - \\
\hline GVHD response after ileostomy & $n$ & $\%$ & & \\
\hline Complete response & 6 & 60 & - & - \\
\hline Partial response & 3 & 30 & - & - \\
\hline No response & 1 & 10 & - & - \\
\hline Cause of death & $n$ & $\%$ & $n$ & $\%$ \\
\hline Acute GVHD & 1 & 10 & 17 & 31 \\
\hline Chronic GVHD & 1 & 10 & 0 & 0 \\
\hline Sepsis & 1 & 10 & 15 & 27 \\
\hline Aspergillosis & 1 & 10 & 9 & 16 \\
\hline ARDS & 0 & 0 & 7 & 13 \\
\hline Encephalopathies & 0 & 0 & 2 & 4 \\
\hline Viral encephalitis & 0 & 0 & 1 & 2 \\
\hline Cardiovascular $^{\dagger}$ & 2 & 20 & 1 & 2 \\
\hline Secondary neoplasia & 1 & 10 & 0 & 0 \\
\hline
\end{tabular}

$A R D S$ acute respiratory distress syndrome, $C N S$ central nervous system

${ }^{\dagger}$ Stroke, pulmonary embolism, and sudden hearth death

second-line treatments, while steroid-resistant liver aGVHD remained a challenge to treatment and accounted for $10 \%$ of deaths in both cohorts. Cox regression analysis (Table 4) confirmed the OS benefit of ileostomy (hazard ratio (HR) 0.54
(95\% confidence interval $(\mathrm{CI}), 0.36-0.81 ; p=0.003)$. This result was also verified by a time-dependent Cox regression analysis (HR 0.36 ; 95\% CI, 0.16-0.80; $p=0.013$ ). After censoring all patients with early death $(<$ day +100 of 


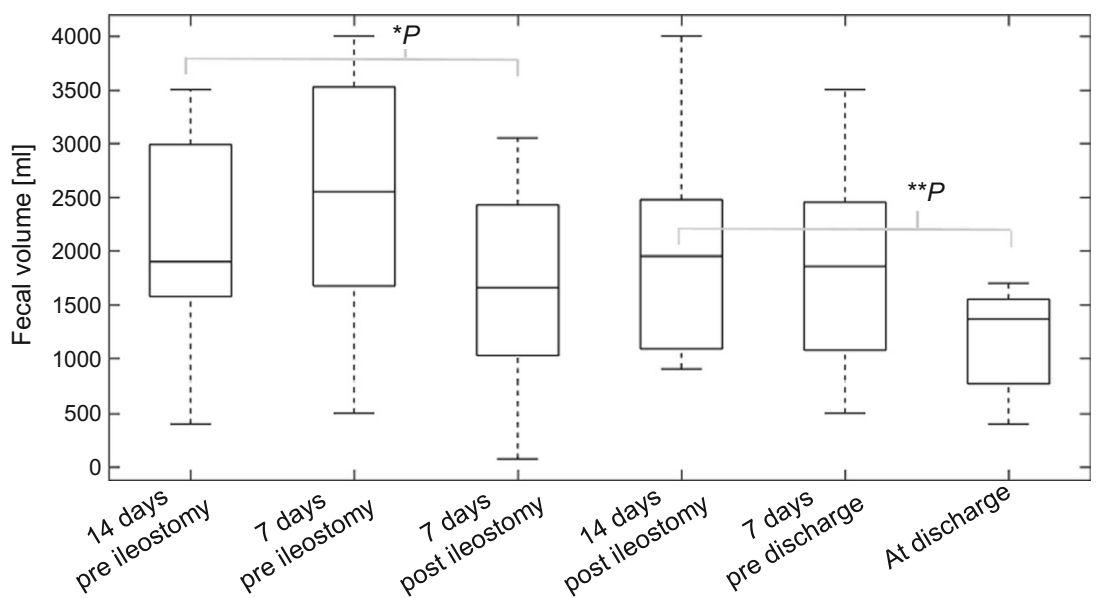

Fig. 1 Significant decline of fecal volumes after ileostomy. Change of fecal volumes per day was evaluated at days 14 and 7 before $(n=9)$ and after ileostomy $(n=8)$ and at discharge $(n=7)$. The significance of the fecal volume changes was evaluated within the paired sample t test. Fecal

transplantation) of any cause, ileostomy still associated with longer OS (HR 0.63; 95\% CI, 0.41-0.95; $p=0.029$ ). Similar results were obtained when OS was evaluated from the date of GVHD diagnosis (HR 0.53; 95\% CI, 0.36-0.82; $p=0.001$ ). Multivariate analysis revealed no significant OS benefit for most second-line therapies (Table 4), likely due to limited patient numbers in each second-line therapy subgroup. ATG (50\% vs $42 \%)$ and basiliximab (10\% vs $16 \%)$ therapies were evenly distributed in both cohorts, while ruxolitinib (30\% vs $5 \%$ ) was underrepresented in the conventional therapy cohort, without resulting in significant OS differences, when stratified with respect to treatment (Table 4, Supplementary Table 2). The application of mycophenolate mofetil (MMF) associated with significantly longer OS $(p=0.014)$, but MMF use volumes after ileostomy were significantly lower as compared to volumes before ileostomy. Significance levels of fecal volume change between 14 days prior to ileostomy and 7 days after ileostomy were $* p=0.02$ and $* * p<0.01$.

overlapped with baseline immunosuppression. Combination of second-line therapies had no significant OS advantage. Patients with GVHD response to any second-line therapy had a significant survival benefit (HR 0.30; 95\% CI, 0.16$0.57 ; p<0.0005$ ). As expected for stage 4 aGVHD, involvement of all 3 organs associated with significantly reduced OS (HR 4.23; 95\% CI, 1.22-14.7). Subgroup analysis of the ileostomy cohort revealed no significant difference regarding the time point of aGVHD diagnosis and of ileostomy surgery.

\section{Correlative studies}

With respect to tested biomarkers, the ileostomy cohort was representative of the whole study cohort with severe GI-
Fig. 2 Comparison of overall survival of GI-aGVHD patients with additional ileostomy and conventional therapy alone. Survival from day of allogeneic stem cell transplantation until death of any cause. Data were censored after 60 months. Patients with GI-aGVHD were categorized into ileostomy $(n=10$, hatched) and conventional therapy cohorts ( $n=55$, solid). Graphs were plotted with the KaplanMeier survival analysis. Cohorts were compared using the log-rank test. ${ }^{*} p=0.002$

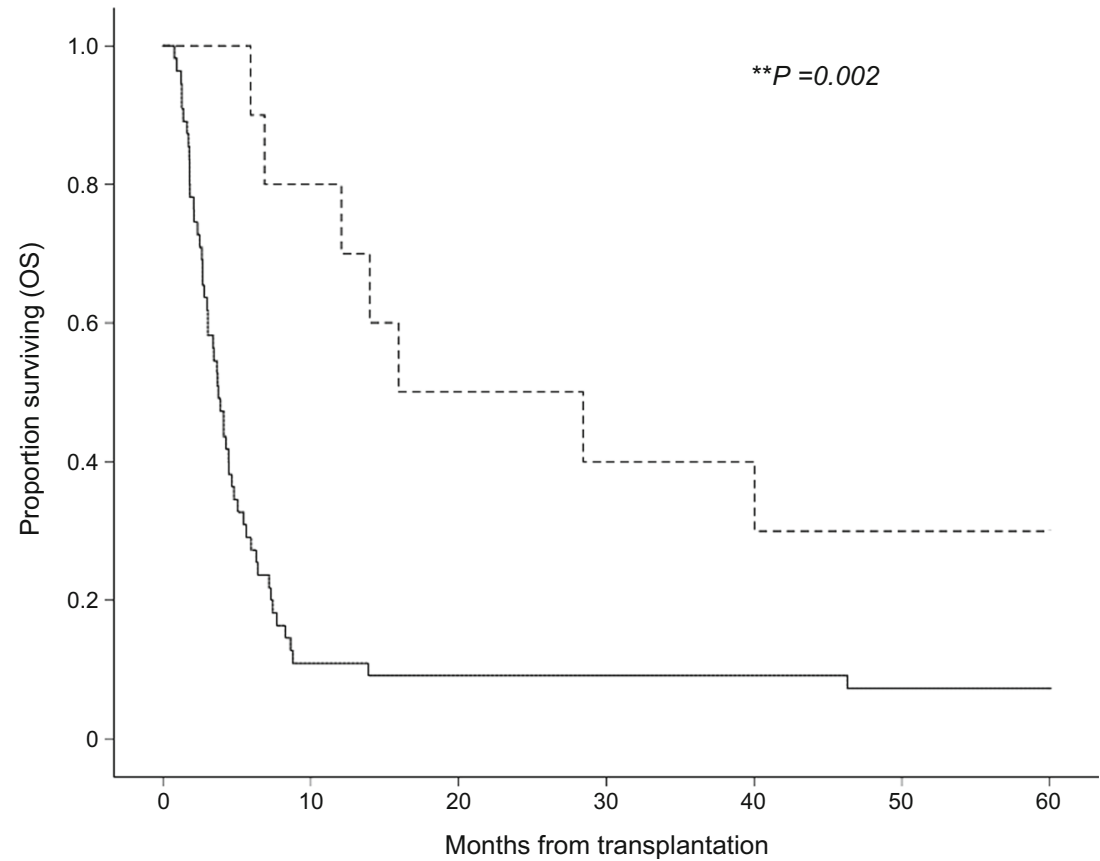


Table 4 Cox regression analysis for HR of competing risks

\begin{tabular}{|c|c|c|c|}
\hline Predictor & HR & $95 \% \mathrm{CI}$ & $p$ \\
\hline \multicolumn{4}{|c|}{ With respect to the survival from transplantation date, all patients } \\
\hline Ileostomy cohort & 0.54 & $0.36-0.81$ & $* * 0.003$ \\
\hline Ileostomy cohort (time-dependent analysis) & 0.36 & $0.16-0.80$ & $* 0.013$ \\
\hline Time to GVHD (effect of 1 day increase) & 1.00 & $0.99-1.00$ & 0.491 \\
\hline Time to ileostomy (effect of 1 day increase) & 1.00 & $0.99-1.01$ & 0.918 \\
\hline \multicolumn{4}{|l|}{ Multivariate Cox-Regression analysis, all patients } \\
\hline GI-GVHD stage 3 vs 4 & 0.90 & $0.41-2.00$ & 0.803 \\
\hline Stage 4 GVHD of skin, gut, and liver & 4.23 & $1.22-14.7$ & $* 0.023$ \\
\hline Acute myeloid leukemia & 0.97 & $0.55-1.68$ & 0.902 \\
\hline Myelodysplastic syndromes & 0.81 & $0.48-2.54$ & 0.780 \\
\hline \multicolumn{4}{|l|}{ Second-line therapy } \\
\hline Anti-thymocyte globulin & 0.66 & $0.39-1.14$ & 0.141 \\
\hline Ruxolitinib & 0.48 & $0.20-1.16$ & 0.101 \\
\hline Mycophenolate mofetil & 0.42 & $0.21-0.84$ & $* 0.014$ \\
\hline Basiliximab & 1.04 & $0.51-2.05$ & 0.946 \\
\hline \multicolumn{4}{|l|}{ Response to second-line treatments } \\
\hline Patients with response & 0.30 & $0.16-0.57$ & $* *<0.0005$ \\
\hline Patients with complete response & 0.08 & $0.10-0.61$ & $* 0.015$ \\
\hline \multicolumn{4}{|l|}{ With respect to the survival from GVHD date, all patients } \\
\hline Ileostomy cohort (all patients) & 0.53 & $0.36-0.82$ & $* * 0.001$ \\
\hline Ileostomy cohort (time-dependent analysis, all patients) & 0.26 & $0.15-0.46$ & $* *<0.0005$ \\
\hline \multicolumn{4}{|c|}{ With respect to the survival from transplantation date, patients survived day $+100(n=42)$} \\
\hline Ileostomy cohort & 0.63 & $0.41-0.95$ & $* 0.029$ \\
\hline
\end{tabular}

$H R$ hazard ratio, $C I$ confidence interval, $p$ significance as $p$ value $* p<0.05, * * p<0.01$
aGVHD. In both cohorts, mean fecal calprotectin values during aGVHD were significantly elevated compared to normal controls, reflecting the severity of inflammation (Table 2). Mean serum s-IL2 R levels of both cohorts were comparable and not predictive of GVHD. Flow cytometry analysis of patient's immune reconstitution before and after ileostomy revealed changes in several T cell subsets. The absolute number of activated T cells significantly decreased by more than $50 \%$ $(p=0.04)$ after experimental surgery, while the number of regulatory $\mathrm{T}$ cells increased by 1.7 -fold $(p=0.28)$ (Fig. 3). The total number of $\mathrm{T}$ cells and $\mathrm{CD}^{+} \mathrm{T}$ cells remained unchanged, while memory T cells increased 1.5-fold $(p=0.19)$. In the experimental ileostomy cohort, stool samples recorded prior transplantation, during GVHD, and after ileostomy revealed an increased presence of aerobic, anaerobic bacteria, and fungi following ileostomy compared to samples obtained during GVHD (Fig. 4). Aerobic bacteria were predominantly present after ileostomy (9 of 9 evaluable patients). For 3 patients $(30 \%)$, all with final ileostomy removal, high numbers of anaerobic bacteria were recorded after GVHD diagnosis and ileostomy. These data indicate that ileostomy induced clinical response in patients with steroid-resistant GVHD along with reduction of pro-inflammatory immune cells and changes of the intestinal microbiota.

\section{Discussion}

This is the first study comparing ileostomy for the treatment of steroid-resistant aGVHD to conventional medical therapy in allogeneic stem cell recipients. Patients with stage 4 GIaGVHD were treated with conventional therapy and received additional experimental ileostomy surgery in order to control GVHD. The majority of patients responded to ileostomy therapy and had a significant OS benefit compared to conventional medical care, alone. In the reported GI-aGVHD cohorts, prolonged immunosuppression together with infectious- and GVHD-associated complications limited long-time survival. The observed mortality rate was consistent compared to reported rates from studies involving GI-aGVHD patients [24, $35,36]$, yet the proportion of stage 4 GI-aGVHD patients was higher. In the ileostomy cohort, enhanced control of intestinal aGVHD resulted in reduced exposure to immunosuppressive medication and may have limited infectious complications. 


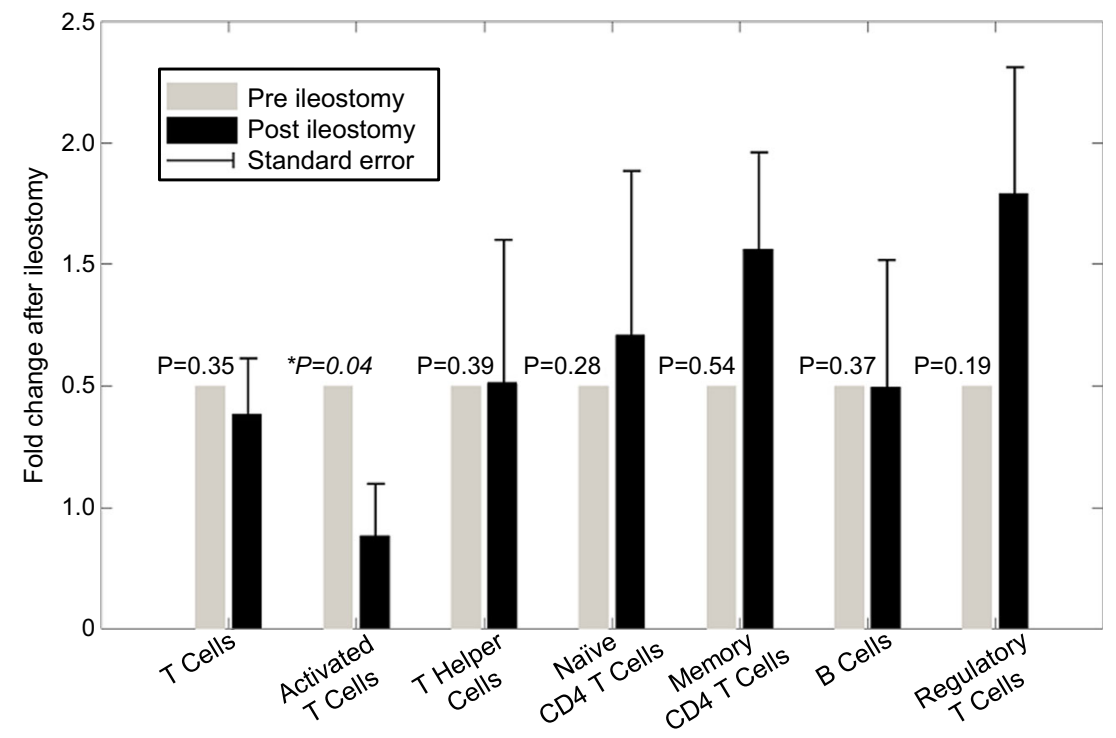

Fig. 3 Ileostomy reduced activated $\mathrm{T}$ cells and increased regulatory $\mathrm{T}$ cells. Lymphocyte subsets in the peripheral blood were measured by flow cytometry before and after ileostomy. Specific cell subsets within the $\mathrm{CD} 45^{+}$lymphocyte gate were characterized as follows: $\mathrm{T}$ cells, $\mathrm{CD} 3^{+}$ $(n=7)$; T helper cells, $\mathrm{CD}^{+} / \mathrm{CD}^{+}(n=6)$; activated T cells, $\mathrm{CD}^{+} / \mathrm{HLA}-$ $\mathrm{DR}^{+}(n=7)$; regulatory $\mathrm{T}$ cells, $\mathrm{CD}^{+} / \mathrm{CD}^{+} / \mathrm{CD} 25^{+} / \mathrm{CD} 127^{-}(n=7)$; naïve $\mathrm{CD}^{+} \mathrm{T}$ cells, $\mathrm{CD}^{+} / \mathrm{CD}^{+} / \mathrm{CD} 45 \mathrm{RA}^{+}(n=5)$; memory $\mathrm{CD}^{+} \mathrm{T}$ cells, $\mathrm{CD}^{+} / \mathrm{CD}^{+} / \mathrm{CD} 45 \mathrm{RO}^{+}(n=6)$; B cells, CD $19^{+}(n=6)$. Fold change of $\mathrm{T}$ cells is expressed as a percentage of absolute cell numbers after ileostomy relative to that observed before ileostomy, and analyzed by the paired sample t test. $p$ values are detailed in the figure. $p<0.05$ was considered statistically significant. Data represents normalized mean values and the error bars represent the standard error of the mean

\section{(2)}

a

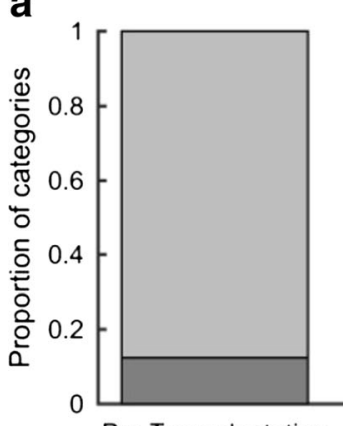

Pre Transplantation
Aerobic

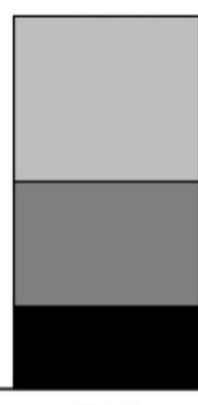

GVHD

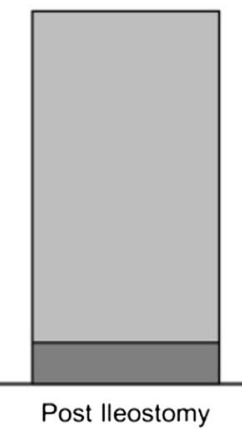

C

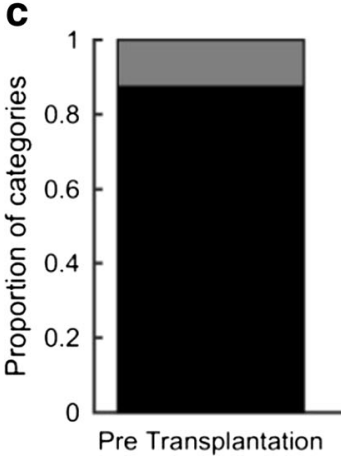

Fungi

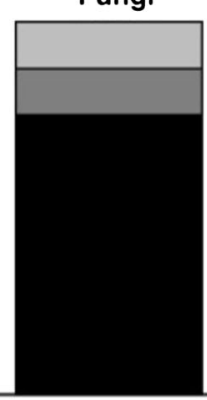

GVHD

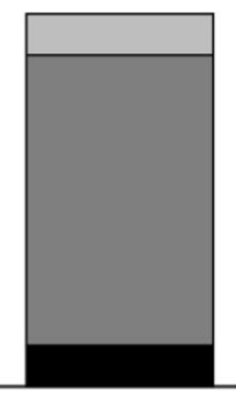

Post lleostomy

Fig. 4 Ileostomy altered the fecal microbiota. Quantitative evaluation of cultured aerobic, anaerobic bacteria, and fungi from fecal samples. Patients were evaluated pre-transplantation $\left(n_{\text {pre }}=8\right)$, during GVHD $\left(n_{\mathrm{GVHD}}=9\right)$, and post-ileostomy $\left(n_{\mathrm{post}}=9\right)$. Microbiota are categorized into low, medium, and high categories according to culture plate counts. The proportion of categories at these time points are shown. a

b

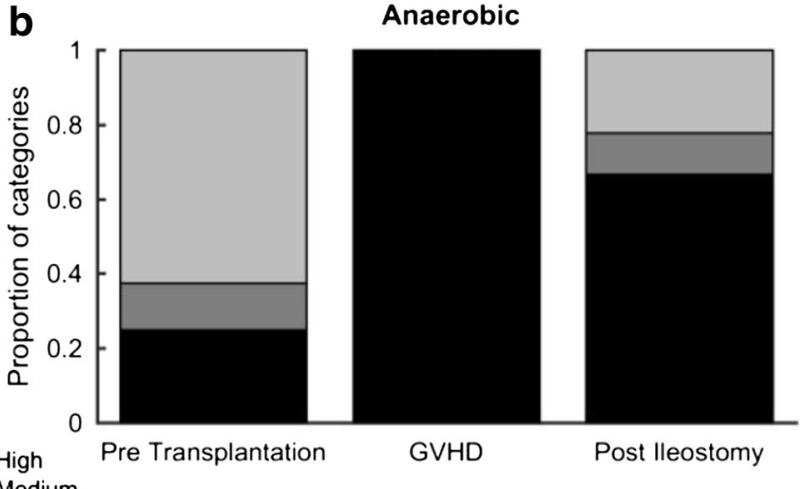

d

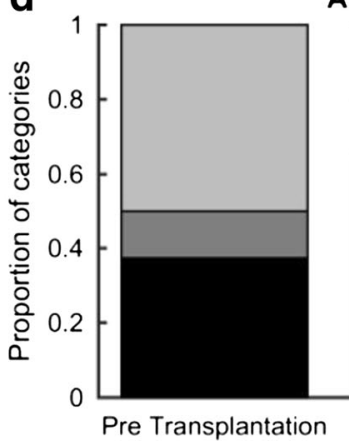

All microorganisms

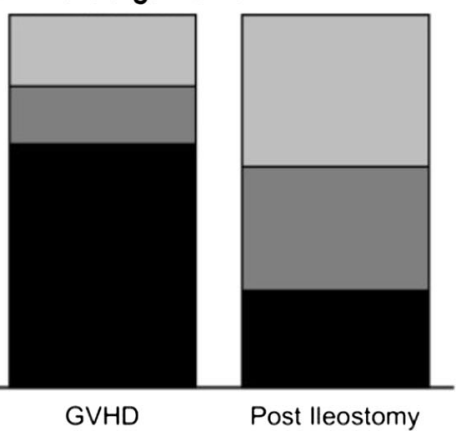

Quantitative evaluation of cultured aerobic bacteria pre-transplantation $\left(n_{\text {pre }}=8\right)$, during GVHD $\left(n_{\mathrm{GVHD}}=9\right)$, and post-ileostomy $\left(n_{\text {post }}=9\right)$. b Quantitative evaluation of cultured anaerobic bacteria $\left(n_{\mathrm{pre}}=8, n_{\mathrm{GVHD}}=\right.$ $\left.9, n_{\text {post }}=9\right)$. c Quantitative evaluation of cultured fungi $\left(n_{\text {pre }}=8\right.$, $\left.n_{\mathrm{GVHD}}=8, n_{\text {post }}=9\right)$. $\mathbf{d}$ Quantitative evaluation of all cultured microorganisms $\left(n_{\text {pre }}=24, n_{\mathrm{GVHD}}=26, n_{\text {post }}=27\right)$ 
Due to the small patient number in the ileostomy cohort, we did not record a significant OS difference between early or late ileostomy (Table 4). In the conventional therapy cohort, the highest mortality was caused by infections, followed by GVHD. The association between GVHD and infectious - in particular invasive fungal [37] — complications has been previously well established, as GVHD associates inflammation, tissue damage, and severe immunosuppression [4]. The intestinal barrier function is disturbed [38], bacterial invasion eased [39], and immune cells are functionally impaired [40-42].

In GI-aGVHD patients, ileostomy resulted in a significant reduction of fecal volumes (Fig. 2), through processes involving, for example, intestinal adaptation, ileostomy-induced immune modulation, and changes of the intestinal microbiota. Post-ileostomy complications include high output [43] as a result of shortened gut surface [44], which may in particular occur in the early post-operative phase of ileostomy [45, 46], an observation that we shared in our study. Within 7 days from surgery, fecal volumes were reduced. Correlative studies in our patients before and after ileostomy support the hypothesis of ileostomy-induced immune modulation. Prior ileostomy, patients had elevated calprotectin values, which may be used as prognostic marker for GI-aGVHD [34, 47]. Patients' cellular immune status also showed elements of inflammation, such as reduced levels of regulatory T cells and elevated levels of activated $\mathrm{T}$ cells. Reducing inflammation can contribute to limit fecal volumes [48]. T cell subset analysis revealed significantly reduced activated $\mathrm{T}$ cells after ileostomy, while the number of regulatory $\mathrm{T}$ cells and memory $\mathrm{T}$ cells increased (Fig. 3). In previous studies of successful GVHD treatments, $\mathrm{T}$ cell subset correlations associated with reduced activated $\mathrm{T}$ cells [10] or increased regulatory T cells $[5,49]$. Due to the small patient number in the ileostomy cohort, changes of memory $\mathrm{T}$ cells and regulatory $\mathrm{T}$ cells remained below significance. Activated $\mathrm{CD}^{+} \mathrm{T}$ cells play a central role in GVHDinduced organ damage [50]. Their significant decrease as a result of ileostomy-induced immune modulation may help to explain why ileostomy proved successful in GVHD patients. Other previously described candidate pathways of ileostomyinduced immune modulation involve EGFR, whose expression was increased after ileostomy in zebrafish [15] and the mucosal cytokine interleukin-22 (IL-22). Reduced intestinal physical stimulation after ileostomy altered the expression of IL-22 [51] and 648 other intestinal genes. In IL-22-deficient recipient mice with GVHD, intestinal apoptosis and mortality were significantly increased [52], while IL-22-deficient donor T cells decreased mortality in GVHD mice [53].

A number of studies indicate that the intestinal microbiota plays an important role in aGVHD [54, 55] and a pilot study of fecal microbiota transfer induced complete response in 3 of 4 patients [56]. We detected changes of intestinal microbiota from pre-transplantation to GVHD and after ileostomy. During GVHD, the detectable number of cultured fecal microbes was lower compared to pre-transplantation samples (Fig. 4). In post-ileostomy fecal samples, the number of aerobic bacteria was higher than during GVHD. In small bowel transplants and ileostomy recipients, increased oxygen levels enhanced intestinal, microbial diversity from strict anaerobic to facultative anaerobic and aerobic bacteria [57]. High intestinal microbiota diversity has been associated with better survival of allogeneic stem cell recipients, due to reduced infectious and GVHD-associated mortality [58]. All 3 patients with later ileostomy removal finally achieved high numbers of anaerobic bacteria. Still, the effect of ileostomy on intestinal microbiota is controversial. Ileostomy may result in nutrient deprivation and less diverse microflora of the de-functioned ileum [59], but has also been associated with an enrichment of bacterial metabolites in the proximal ileum [57] and high inter-individual variation of microbiota [60]. We note the following limitations to this analysis. Data has been analyzed retrospectively and the absolute number of patients in the ileostomy cohort was limited. As patients in this study have been treated between 2009 and 2015, the extent of ruxolitinib use varied between cohorts, without resulting in a significant OS difference. Flow cytometric T cell subset analysis was conducted without intracellular staining.

\section{Conclusions}

Despite the limited patient number, our data show that ileostomy represents a promising treatment option for steroid-resistant GI-aGVHD. Correlative studies indicate induction of intestinal adaptation, immune modulation, and changed microbiota through ileostomy. When indicated, ileostomy should be performed before day +100 , because hazards of GVHD-associated and infectious mortality increased in uncontrolled GVHD with time. A prospective, controlled, randomized trial comparing ileostomy to other second-line GVHD treatments should validate these results.

Acknowledgments We would like to thank Dr. Stefanie Bertram for advice on intestinal histopathology, Prof. Katharina Fleischhauer for critical review of the manuscript, and Martina Franke and all other colleagues of the BMT laboratory for technical assistance. Clinical research was supported by the University of Duisburg-Essen.

Authorship ATT, NKS, and DWB designed the study. EB and ATT performed statistical analysis. ATT, JY, JK, AT, and OB performed data collection. TB, JK, and TL participated in data acquisition and analysis. ATT, EB, and NKS wrote the manuscript. DWB, TL, and TB contributed to write the manuscript. All authors had access to primary clinical trial data, read, and approved the final manuscript.

\section{Compliance with ethical standards}

The study and data acquisition was conducted in accordance with German legislation and the revised Helsinki Declaration and evaluated 
by the ethical institutional review board of the University of DuisburgEssen (Protocol No. 18-8220-BO). Written consent to experimental surgical therapy was obtained from all patients with ileostomy. We confirm that no patient can be identified because of anonymized patient data.

Conflict of interest ATT has received lecture fees from Jazz Pharmaceuticals and travel subsidies from Neovii Biotech outside the submitted work. NKS received travel subsidies from MSD and Jazz, DWB received travel subsidies from Medac, all outside the submitted work. The other authors declare that they have no competing interests.

\section{References}

1. Gooley TA, Chien JW, Pergam SA, Hingorani S, Sorror ML, Boeckh M, Martin PJ, Sandmaier BM, Marr KA, Appelbaum FR, Storb R, McDonald GB (2010) Reduced mortality after allogeneic hematopoietic cell transplantation. N Engl J Med 363(22):20912101

2. McDonald GB (2016) How I treat acute graft-versus-host disease of the gastrointestinal tract and the liver. Blood 127(12):1544-1550 10/21/received12/19/accepted

3. MacMillan ML, Weisdorf DJ, Wagner JE, DeFor TE, Burns LJ, Ramsay NK et al (2002) Response of 443 patients to steroids as primary therapy for acute graft-versus-host disease: comparison of grading systems. Biol Blood Marrow Transplant 8(7):387-394

4. Martin PJ, Rizzo JD, Wingard JR, Ballen K, Curtin PT, Cutler C et al (2012 2012/08/01/) First- and second-line systemic treatment of acute graft-versus-host disease: recommendations of the American Society of Blood and Marrow Transplantation. Biol Blood Marrow Transplant 18(8):1150-1163

5. Magenau JM, Goldstein SC, Peltier D, Soiffer RJ, Braun T, Pawarode A, Riwes MM, Kennel M, Antin JH, Cutler CS, Ho VT, Alyea EP III, Parkin BL, Yanik GA, Choi SW, Lewis EC, Dinarello CA, Koreth J, Reddy P (2018) alphal-antitrypsin infusion for treatment of steroid-resistant acute graft-versus-host disease. Blood 131(12):1372-1379

6. Schmidt-Hieber M, Fietz T, Knauf W, Uharek L, Hopfenmuller W, Thiel E, Blau IW (2005) Efficacy of the interleukin-2 receptor antagonist basiliximab in steroid-refractory acute graft-versus-host disease. Br J Haematol 130(4):568-574

7. Rager A, Frey N, Goldstein SC, Reshef R, Hexner EO, Loren A et al (2010 05/24/online) Inflammatory cytokine inhibition with combination daclizumab and infliximab for steroid-refractory acute GVHD. Bone Marrow Transplant 46:430

8. Xhaard A, Rocha V, Bueno B, de Latour RP, Lenglet J, Petropoulou A et al (2012 2012/03/01/) Steroid-refractory acute GVHD: lack of long-term improved survival using new generation anticytokine treatment. Biol Blood Marrow Transplant 18(3):406-413

9. MacMillan ML, Weisdorf DJ, Davies SM, DeFor TE, Burns LJ, Ramsay NK et al (2002) Early antithymocyte globulin therapy improves survival in patients with steroid-resistant acute graft-versushost disease. Biol Blood Marrow Transplant 8(1):40-46

10. Zeiser R, Burchert A, Lengerke C, Verbeek M, Maas-Bauer K, Metzelder SK, Spoerl S, Ditschkowski M, Ecsedi M, Sockel K, Ayuk F, Ajib S, de Fontbrune FS, Na IK, Penter L, Holtick U, Wolf D, Schuler E, Meyer E, Apostolova P, Bertz H, Marks R, Lübbert M, Wäsch R, Scheid C, Stölzel F, Ordemann R, Bug G, Kobbe G, Negrin R, Brune M, Spyridonidis A, Schmitt-Gräff A, van der Velden W, Huls G, Mielke S, Grigoleit GU, Kuball J, Flynn R, Ihorst G, du J, Blazar BR, Arnold R, Kröger N, Passweg J, Halter J, Socié G, Beelen D, Peschel C, Neubauer A, Finke J, Duyster J, von Bubnoff N (2015) Ruxolitinib in corticosteroid-refractory graft-versus-host disease after allogeneic stem cell transplantation: a multicenter survey. Leukemia 29(10):2062-2068

11. Wolff D, Ayuk F, Elmaagacli A, Bertz H, Lawitschka A, Schleuning M, Meyer RG, Gerbitz A, Hilgendorf I, Hildebrandt GC, Edinger M, Klein S, Halter J, Mousset S, Holler E, Greinix HT (2013) Current practice in diagnosis and treatment of acute graft-versus-host disease: results from a survey among German-Austrian-Swiss hematopoietic stem cell transplant centers. Biology of blood and marrow transplantation : journal of the American Society for Blood and Marrow Transplantation. 19(5):767-776

12. Welters CF, Dejong CH, Deutz NE, Heineman E (2002) Intestinal adaptation in short bowel syndrome. ANZ J Surg 72(3):229-236

13. Sangild PT, Ney DM, Sigalet DL, Vegge A, Burrin D (2014 2014/12/15) Animal models of gastrointestinal and liver diseases. Animal models of infant short bowel syndrome: translational relevance and challenges. Am J Physiol Gastrointest Liver Physiol 307(12):G1147-G1G68

14. Koffeman GI, Hulscher JBF, Schoots IG, van Gulik TM, Heij HA, van Gemert WG (2015 2015/05/15/) Intestinal lengthening and reversed segment in a piglet short bowel syndrome model. J Surg Res 195(2):433-443

15. Schall KA, Holoyda KA, Grant CN, Levin DE, Torres ER, Maxwell A et al (2015 2015/08/01) Adult zebrafish intestine resection: a novel model of short bowel syndrome, adaptation, and intestinal stem cell regeneration. Am J Physiol Gastrointest Liver Physiol 309(3):G135-GG45

16. Fowler KL, Wieck MM, Hilton AE, Hou X, Schlieve CR, Grikscheit TC (2017) Marked stem/progenitor cell expansion occurs early after murine ileostomy: a new model. J Surg Res 220: 182-196

17. Ziegler TR, Mantell MP, Chow JC, Rombeau JL, Smith RJ (1998) Intestinal adaptation after extensive small bowel resection: differential changes in growth and insulin-like growth factor system messenger ribonucleic acids in jejunum and ileum. Endocrinology. 139(7):3119-3126

18. Canguilhem B, Pradines A, Baudouin C, Boby C, Lajoie-Mazenc I, Charveron M, Favre G (2005) RhoB protects human keratinocytes from UVB-induced apoptosis through epidermal growth factor receptor signaling. J Biol Chem 280(52):43257-43263

19. Zaiss DM, van Loosdregt J, Gorlani A, Bekker CP, Grone A, Sibilia $M$ et al (2013) Amphiregulin enhances regulatory T cellsuppressive function via the epidermal growth factor receptor. Immunity. 38(2):275-284

20. Du P, Sun C, Ashburn J, Wu X, Philpott J, Remzi FH et al (2015) Risk factors for Crohn's disease of the neo-small intestine in ulcerative colitis patients with total proctocolectomy and primary or secondary ileostomies. J Crohns Colitis 9(2):170-176

21. Kotze PG, Bremer-Nones R, Kotze LM (2014) Is there any relation between gastric bypass for morbid obesity and the development of Crohn's disease? J Crohns Colitis 8(7):712-713

22. Amin K, Usman Y, Schultz B, Vaughn B, Howard J, Khoruts A, Defor TE, Forster C, Rashidi A, Weisdorf DJ, MacMillan ML, Blazar BR, Mortari A, Holtan SG (2018) Low amphiregulin expression in intestinal biopsies of patients with acute graft-versus-host disease. Biol Blood Marrow Transplant 24(3):S188

23. Holtan SG, Khera N, Levine JE, Chai X, Storer B, Liu HD, Inamoto Y, Chen GL, Mayer S, Arora M, Palmer J, Flowers MED, Cutler CS, Lukez A, Arai S, Lazaryan A, Newell LF, Krupski C, Jagasia MH, Pusic I, Wood W, Renteria AS, Yanik G, Hogan WJ, Hexner E, Ayuk F, Holler E, Watanaboonyongcharoen P, Efebera YA, Ferrara JLM, Panoskaltsis-Mortari A, Weisdorf D, Lee SJ, Pidala $\mathrm{J}$ (2016) Late acute graft-versus-host disease: a prospective analysis of clinical outcomes and circulating angiogenic factors. Blood 128(19):2350-2358 
24. Irani JL, Cutler CS, Whang EE et al (2008) Severe acute gastrointestinal graft-vs-host disease: an emerging surgical dilemma in contemporary cancer care. Arch Surg 143(11):1041-1045

25. Evans J, Percy J, Eckstein R, Ma D, Schnitzler M (1998) Surgery for intestinal graft-versus-host disease: report of two cases. Dis Colon Rectum 41(12):1573-1576

26. Herr A-L, Latulippe J-F, Carignan S, Mitchell A, Bélanger R, Roy J (2004) Is severe intestinal chronic graft-versus-host disease an indication for surgery? A report of two cases. Transplantation 77(10): $1617-1620$

27. Cornell RF, Palmer J, Komorowski R, Drobyski WR (2012 10// print) Surgical resection as definitive treatment for refractory GVHD of the colon. Bone Marrow Transplant 47(10):1366-1367

28. Glucksberg H, Storb R, Fefer A, Buckner CD, Neiman PE, Clift RA et al (1974) Clinical manifestations of graft-versus-host disease in human recipients of marrow from HL-A-matched sibling donors. Transplantation 18(4):295-304

29. Harris AC, Young R, Devine S, Hogan WJ, Ayuk F, Bunworasate U, Chanswangphuwana C, Efebera YA, Holler E, Litzow M, Ordemann R, Qayed M, Renteria AS, Reshef R, Wölfl M, Chen YB, Goldstein S, Jagasia M, Locatelli F, Mielke S, Porter D, Schechter T, Shekhovtsova Z, Ferrara JLM, Levine JE (2016) International, multicenter standardization of acute graft-versushost disease clinical data collection: a report from the Mount Sinai Acute GVHD International Consortium. Biol Blood Marrow Transplant 22(1):4-10

30. Kreisel W, Dahlberg M, Bertz H, Harder J, Potthoff K, Deibert P, Schmitt-Graeff A, Finke J (2012) Endoscopic diagnosis of acute intestinal GVHD following allogeneic hematopoietic SCT: a retrospective analysis in 175 patients. Bone Marrow Transplant 47(3): $430-438$

31. Levine JE, Logan B, Wu J, Alousi AM, Ho V, Bolanos-Meade J et al (2010) Graft-versus-host disease treatment: predictors of survival. Biol Blood Marrow Transplant 16(12):1693-1699

32. Health NIo (2009) Common Terminology Criteria for Adverse Events (CTCAE). In: SERVICES USDOHAH

33. Miyamoto T, Akashi K, Hayashi S, Gondo H, Murakawa M, Tanimoto K et al (1996) Serum concentration of the soluble interleukin-2 receptor for monitoring acute graft-versus-host disease. Bone Marrow Transplant 17(2):185-190

34. Adam B, Koldehoff M, Ditschkowski M, Gromke T, Hlinka M, Trenschel R, Kordeals L, Steckel NK, Beelen DW, Liebregts T (2016) Endoscopic and histological findings are predicted by fecal calprotectin in acute intestinal graft-versus-host-disease. Dig Dis Sci 61(7):2019-2026

35. Ayuk F, Bussmann L, Zabelina T, Veit R, Alchalby H, Wolschke C et al (2014 2014/05/01) Serum albumin level predicts survival of patients with gastrointestinal acute graft-versus-host disease after allogeneic stem cell transplantation. Ann Hematol 93(5):855-861

36. Castilla-Llorente C, Martin PJ, McDonald GB, Storer BE, Appelbaum FR, Deeg HJ et al (2014) Prognostic factors and outcomes of severe gastrointestinal GVHD after allogeneic hematopoietic cell transplantation. Bone Marrow Transplant 49(7):966971

37. Ullmann AJ, Lipton JH, Vesole DH, Chandrasekar P, Langston A, Tarantolo SR, Greinix H, Morais de Azevedo W, Reddy V, Boparai N, Pedicone L, Patino H, Durrant S (2007) Posaconazole or fluconazole for prophylaxis in severe graft-versus-host disease. N Engl $\mathrm{J}$ Med 356(4):335-347

38. Noth R, Lange-Grumfeld J, Stuber E, Kruse ML, Ellrichmann M, Hasler R et al (2011) Increased intestinal permeability and tight junction disruption by altered expression and localization of occludin in a murine graft versus host disease model. BMC Gastroenterol 11:109

39. Schwab L, Goroncy L, Palaniyandi S, Gautam S, Triantafyllopoulou A, Mocsai A, Reichardt W, Karlsson FJ,
Radhakrishnan SV, Hanke K, Schmitt-Graeff A, Freudenberg M, von Loewenich FD, Wolf P, Leonhardt F, Baxan N, Pfeifer D, Schmah O, Schönle A, Martin SF, Mertelsmann R, Duyster J, Finke J, Prinz M, Henneke P, Häcker H, Hildebrandt GC, Häcker G, Zeiser R (2014) Neutrophil granulocytes recruited upon translocation of intestinal bacteria enhance graft-versus-host disease via tissue damage. Nat Med 20(6):648-654

40. Dudakov JA, Mertelsmann AM, O'Connor MH, Jenq RR, Velardi E, Young LF et al (2017) Loss of thymic innate lymphoid cells leads to impaired thymopoiesis in experimental graft-versus-host disease. Blood 130(7):933-942

41. Bunting MD, Varelias A, Souza-Fonseca-Guimaraes F, Schuster IS, Lineburg KE, Kuns RD, Fleming P, Locke KR, Huntington ND, Blazar BR, Lane SW, Tey SK, MacDonald KPA, Smyth MJ, DegliEsposti MA, Hill GR (2017) GVHD prevents NK-cell-dependent leukemia and virus-specific innate immunity. Blood 129(5):630 642

42. Mensen A, Johrens K, Anagnostopoulos I, Demski S, Oey M, Stroux A, Hemmati P, Westermann J, Blau O, Wittenbecher F, Movassaghi K, Szyska M, Thomas S, Dorken B, Scheibenbogen C, Arnold R, Na IK (2014) Bone marrow T-cell infiltration during acute GVHD is associated with delayed B-cell recovery and function after HSCT. Blood 124(6):963-972

43. Baker ML, Williams RN, Nightingale JM (2011) Causes and management of a high-output stoma. Color Dis 13(2):191-197

44. O'Keefe SJ, Buchman AL, Fishbein TM, Jeejeebhoy KN, Jeppesen PB, Shaffer J (2006) Short bowel syndrome and intestinal failure: consensus definitions and overview. Clin Gastroenterol Hepatol 4(1):6-10

45. Park J, Gessler B, Block M, Angenete E (2018) Complications and morbidity associated with loop ileostomies in patients with ulcerative colitis. Scand J Surg 107(1):38-42

46. Heikens JT, Gooszen HG, Teepen JL, Hueting WE, Oostvogel HJ, van Vroonhoven TJ et al (2013) The ileo neo rectal anastomosis: long-term results of surgical innovation in patients after ulcerative colitis and familial adenomatous polyposis. Int J Color Dis 28(1): $111-118$

47. Rodriguez-Otero P, Porcher R, Peffault de Latour R, Contreras M, Bouhnik Y, Xhaard A et al (2012) Fecal calprotectin and alpha-1 antitrypsin predict severity and response to corticosteroids in gastrointestinal graft-versus-host disease. Blood 119(24):5909-5917

48. Gareau MG, Barrett KE (2013 2013/12/01/) Fluid and electrolyte secretion in the inflamed gut: novel targets for treatment of inflammation-induced diarrhea. Curr Opin Pharmacol 13(6):895899

49. Koreth J, Matsuoka K, Kim HT, McDonough SM, Bindra B, Alyea EP 3rd et al (2011) Interleukin-2 and regulatory T cells in graftversus-host disease. N Engl J Med 365(22):2055-2066

50. Blazar BR, Murphy WJ, Abedi M (2012 05/11/online) Advances in graft-versus-host disease biology and therapy. Nat Rev Immunol $12: 443$

51. Wieck MM, Schlieve CR, Thornton ME, Fowler KL, Isani M, Grant CN et al (2017 01/2406/08/received12/20/accepted) Prolonged absence of mechanoluminal stimulation in human intestine alters the transcriptome and intestinal stem cell niche. Cell Mol Gastroenterol Hepatol 3(3):367-88.e1

52. Hanash Alan M, Dudakov Jarrod A, Hua G, O'Connor Margaret H, Young Lauren F, Singer Natalie V et al (2012 2012/08/24/) Interleukin-22 protects intestinal stem cells from immunemediated tissue damage and regulates sensitivity to graft versus host disease. Immunity 37(2):339-350

53. Couturier M, Lamarthée B, Arbez J, Renauld JC, Bossard C, Malard F et al (2013 02/12/online) IL-22 deficiency in donor T cells attenuates murine acute graft-versus-host disease mortality while sparing the graft-versus-leukemia effect. Leukemia 27:1527 
54. Staffas A, Burgos da Silva M, van den Brink MR (2017) The intestinal microbiota in allogeneic hematopoietic cell transplant and graft-versus-host disease. Blood 129(8):927-933

55. Holler E, Butzhammer P, Schmid K, Hundsrucker C, Koestler J, Peter K et al (2014 2014/05/01/) Metagenomic analysis of the stool microbiome in patients receiving allogeneic stem cell transplantation: loss of diversity is associated with use of systemic antibiotics and more pronounced in gastrointestinal graft-versus-host disease. Biol Blood Marrow Transplant 20(5):640-645

56. Kakihana K, Fujioka Y, Suda W, Najima Y, Kuwata G, Sasajima S, Mimura I, Morita H, Sugiyama D, Nishikawa H, Hattori M, Hino Y, Ikegawa S, Yamamoto K, Toya T, Doki N, Koizumi K, Honda K, Ohashi K (2016) Fecal microbiota transplantation for patients with steroid-resistant acute graft-versus-host disease of the gut. Blood 128(16):2083-2088

57. Hartman AL, Lough DM, Barupal DK, Fiehn O, Fishbein T, Zasloff M, Eisen JA (2009) Human gut microbiome adopts an alternative state following small bowel transplantation. Proc Natl Acad Sci 106(40):17187-17192
58. Taur Y, Jenq RR, Perales MA, Littmann ER, Morjaria S, Ling L, No D, Gobourne A, Viale A, Dahi PB, Ponce DM, Barker JN, Giralt S, van den Brink M, Pamer EG (2014) The effects of intestinal tract bacterial diversity on mortality following allogeneic hematopoietic stem cell transplantation. Blood 124(7):1174-1182

59. Beamish EL, Johnson J, Shaw EJ, Scott NA, Bhowmick A, Rigby $\mathrm{RJ}$ (2017) Loop ileostomy-mediated fecal stream diversion is associated with microbial dysbiosis. Gut Microbes 8(5):467-478

60. Booijink CC, El-Aidy S, Rajilic-Stojanovic M, Heilig HG, Troost FJ, Smidt $\mathrm{H}$ et al (2010) High temporal and inter-individual variation detected in the human ileal microbiota. Environ Microbiol 12(12):3213-3227

Publisher's note Springer Nature remains neutral with regard to jurisdictional claims in published maps and institutional affiliations. 